\title{
OBITUARY
}

\section{Nawab Imadul Mulk Bahadur Sayed Husain Bilgrani}

On 3rd June died after a short illness, at the age of 85 years, at his residence in Saifabad, a suburb of Hyderabad, a man and scholar who was revered far beyond the confines of India. Sayed Husain was born at Sahibganj, Gaya, in the year 1842 as the son of Sayed Zainuddin Husain Khān, who was a magistrate in Behar, one of the first Muhammadans appointed to such a position. Sayed Husain enjoyed an excellent education under the care of private tutors and acquired through his father's teaching a mastery of the English language hardly ever equalled by any other foreigner. He was finally sent to the La Martinière College at Calcutta where he matriculated at the Hare Academy. He then entered the Presidency College and took his degree after four years' study. In 1868, at the age of 26, he was appointed to the chair of Arabic at the Canning College in.Lucknow, being at the same time, on account of his proficiency in English, made chief editor of the Lucknow Times, at that period a very influential paper among the landowners of the province. In 1872 the great Minister of the State of Hyderabad, Sir Salär Jang, recognizing his merits, invited him to enter the service of that State, which invitation he accepted in the following year. From that time all his energies were devoted to the service of this, the paramount independent Indian State, and the enlightenment of its subjects. At first private secretary of Sir Salār Jang, he became subsequently Educational Secretary and Director of Public Instruction. How highly he was honoured by his sovereigns can be estimated from the fact that during his long service to the State he was appointed in succession tutor to His Highness the late Niẓām Mir Maḥbūb 'Alī Khān, to his Exalted Highness the ruling Nizām, and to the princes of the latter.

Though a politician by virtue of his offices it is mainly due to his efforts that most of the educational institutions in the State were inaugurated, and the latest of these, though not directly due to him, the Osmania University and the new Girls' School, are the result of his example. But it was not only in the establishment of schools and colleges that he worked for the development of the intellectual advancement of Indians. He, assisted by a number of high-minded and generous friends, initiated a Society, known under the title of VOL. IV. PART II. 
“Dā'iratul Mā'arif ", for the publication of important and rare Arabic works to enable Muslims, not of India alone but of the whole Muhammadan world, to study at moderate prices the masterpieces of their literature. At the time of his death no less than fifty-seven separate works had been issued by the Press established for this purpose. We owe to the efforts of the Dā'ira the publication of many works of which manuscripts are either entirely lacking or only in fragments in the great libraries of Europe. As early as 1872 he had urged the publication of the great Optics of Ibn al-Haitham, one of the chief scientific works composed by the Arabs in the Middle Ages. Only one manuscript, that in the Leiden Library, was known to Oriental scholars, but by diligent search four more copies were brought to light in India, and sparing no expense an edition was prepared, of which the last sheets of a final revision were ready shortly before his death. At the same time the Dâ'ira had undertaken to publish the extensive book on tradition, the Sunan of al-Baihaqi, the Jamhara fil Lugha of Ibn Duraid, the Amāli of Ibn ash-Shajarī, and the biographical dictionary, the Durar al-Kāmina, of Ibn Hajar. Supported as the Imad ul-Mulk was during his life-time by a devoted circle of friends, many of whom I could name, they are determined that the great work incepted by him shall not cease with his death and it has been decided that the work will be carried on under the auspices of the Osmania University, and it is to be hoped that the new arrangement will continue to contribute to the advancement of Muhammadan learning.

The devoted collaboration of so many high-minded friends throws a vivid light upon the personal character of the Imad ul-Mulk; he was untiring and unselfish to the highest degree in assisting friends and scholars; a noble soul and of the purest integrity, a man of whom any land can be proud and who will be greatly missed by all who came into touch with him.

F. KRENKow. 